\title{
飼料への易発酝性炭水化物の添加が乳牛の 糞尿窒素排泄量に及ぼす影響
}

\author{
大谷文博 $\cdot$ 田鎖直澄 ${ }^{a} \cdot$ 上野孝志 ${ }^{\mathrm{a}}$ \\ 農林水産省北海道農業試験場，札幌市豐平区 062-8555
}

(2000.8.3 受付, 2000.12.6 受理)

\begin{abstract}
要 約 飼料への易発酵性炭水化物添加に上る乳牛の糞尿中窒素（N）排泄量低減化の可能性を検討 するため，基礎飼料に $10 \%$ 抢よび $20 \%$ の精製バレイショ測粉を添加して泌乳牛を用いた窒菜出納試験 を実施し，同時に各種生体液成分の变化を観察した，20\%の精製バレイショ洀粉添加により1割弱の残 食が生じ，わずかな粗脂肪㧍よび NDF 消化率之第一胃 $\mathrm{pH} の$ 低下が認めら机たが，乳量および乳質に は有意な添加の影響はなかった。尿中への N 排泄量（率）は港粉添加量の增加に従って有意に減少し，

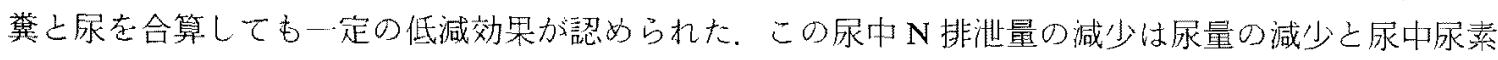
濃度の低下に上るもの之考えられ，いずれの变化も血檙尿素濃度の低下に起因するもの上推測された。 さらに，その血漿尿菜濃度の低下には，第一胃内アンモ二ア濃度の低下抢よびプロピオン酸，乳酸，ピ ルビン酸からの桾新生增加によるアミ，酸の節約効果か関与するものと若えられた．以上加ら，乳牛飼 料へ精䳤バレイショ測粉のような發発酵性炭水化物を添加することによって, 飼料の消化性や乳量・乳 質に大きな影響を与えることなく，粪尿窒素排泄量を低減させる効果加得られ，その発現には血漿尿素 濃度の低下が主要な役割を果たしていることが半朋した。
\end{abstract}

日本畜産学会報，72(8)：J239-J246，2001

飼料資源の多くを海外加らの翰入に依存するわが国の 畜産は，ここ数十年の急速な規模桩大によって耕地還元 量をはるかに超える家甾排泄物老抱えることとなっ た7)、そのため，環境保全への関心が高まるなが，家畜排 泄物に上る環境負荷をいかに低減するかという，重大か つ緊急な問題に面面している。なかです，国内の全家畜 排泄物量の約 3 分の 1 占占码乳牛加らの排泄物に上る 環境負荷を減らすための対策は上くに重要である゙、窒 素（N）は富栄養化物質として徒来加ら法的な排出規制 対象となっていたが，近年，畜産業に適用される排出基 準值がより瑗しい值に改正され，さらに，硝酸態 $\mathrm{N}$ が有 害物質として環境基準項目に追加されるなど規制す強化 されて扝り，処理技術の開発とともに家畜䔬尿中Nの 削減少急務の課題之なっている。しかし，乳牛に括いて その対策老考える際には，N排泄量の低減化を図りなが ら手乳生産在維持させるという視点が必要である24．

反铭家畜の飼料への易発酵性炭水化物の添加は，第一 胃内微生物合成を促谁し，Nの利用効苝在改善する効果 があるこよが知られて甫り ${ }^{14,22,231}$ ，栄養管理に基づいた
排泄 $\mathrm{N}$ 低減化技術のひとつとして，乳牛でも利用でき る上考えら机る。し加し，乳牛人の易発酵性炭水化物の 給与に関しては，第一胃内環境の急激な变化 ${ }^{1.5}$ や乳 量・乳質の低下"10)などのマイナス效果㫗報告されてい る。また， $\mathrm{N}$ 利用効率の改善効果力発現する生体内入力 ニズムについても，必ずしも明確にされているとは言え な(14).

精製潵粉は, 款類や根菜類に含まれる易発酵性炭水化 物である激粉を，もっ上屯速やかに第一胃微生物に利用 させることができる加工形態上思わ机るが，糖類ほよ゙は 急激に発酵されることはない231，そこで，本研究では精 製バレイショ澱粉の飼料への添加によって，乳牛の生産 性を損わることなく糞尿 $\mathrm{N}$ 排泄量を低減することの可

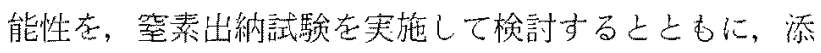
加処理によって生じる各種生体液成分の動態を調べて， 易発酵性炭水化物によるN排泄量低滅化の機序走推定 した.

a現住所：農林水産省畜産試験場, 茨城県筑波農林研究団地 305-0901

連絡者：大谷文博（fax : 011-859-2178, e-mail : ayana@cryo.affrc.go.jp）

Anim. Sci. J. 72 (8)：J239-J246, 2001 


\section{大谷・田鎖・上野}

\section{材料および方法}

供試牛は北海道農業試験場で飼養する泌乳中後期の木 ルスタイン経産牛 3 頭（試験開始時で分娭徯 160-210 日, 平均体重 $727 \mathrm{~kg}$ ) 在用いた。試駼は飼料条件として 表 1 および表 2 に示した構成および成分組成の基礎飼料 のみを給与した $0 \%$ 区，その基礎飼料に精製バレイショ 测粉(ホクレン) 在乾物重量比でをれぞれ10，20\%(平 均実測值 9.0，18.0\%）添加した $10 \%$ 区および $20 \%$ 区の 3 区在設定し，飼料条件を処理因子とし個体，時期索ブ ロック因子とする $3 \times 3$ ラテン方格法によって実施した。 配合飼料は市販品（メイハイ 18 , 明治乳業) を使用した。 また，グラスサイレージは出穂期刚りオーチャードグラ 不主体混播 1 番草を, 乾草は同じく 2 番草を調製したも のを用い、サイレージはタワーサイロから毎日必要量を 取り出して使用した。飼料給与量は試験開始にさきだっ て実施した馴致期間（10日間）の乳量上飼料栄養㑑加 ら，日本鸰養標染 ${ }^{12)}$ の要求量に基づた TDN 充足率考 0\%区でお扎む称 100\%とする予定で，定量を設定した。 飼料は測粉も含めてすべて混合飼料（TMR）上し，1日

Table 1. Ingredient composition of basal diet*

\begin{tabular}{lc}
\hline \hline & $(\% \mathrm{DM})$ \\
\hline Grass silage & 35.9 \\
Dried grass & 7.4 \\
Formula feed & 33.4 \\
Beet pulp & 13.1 \\
Soybean meal & 10.3 \\
\hline
\end{tabular}

* Average value of three trial periods.
2 回に分けて朝晚 2 回の㵠乳（9：00 および 19：00）終 了後に給与した。また，ウォターカップからの飲水は自 由とした。

空菜出納掞よび消化試験は予備期 7 日間，本試験期 7 日間在 1 期上し，本試験期に扔け万全翼尿採取法により 実施した。本試娩期間中は飲水量, 乳量, 䔬量, 尿量, 残飼がある場合には残飼量企個体ごとに毎日定時に測定 し，䪷，尿，残飼は 7 日分在日量に応じて按分泿合して 分析サンプルとした．牛乳は各搾乳時毎のサンプルを分 析サンプルとしたが，分析後に乳量による加重平均を 行って本試験期間にお故る乳成分值とした。

本試験期 6 日目に第一霄液㧍よび血液の採取を行っ た。第一胃液は朝の搾乳終了後の飼料給与直前に，経口 的に採取した。採取した第一胃液はただちに二重がーゼ でろ過し， $\mathrm{pH}$ およびアンモ二ア態 $\mathrm{N}$ 濃度を測定後, 分 析用サンプルとして凍結保存した。また，血液は左側頸 静脈にあらかじめ装着した力テーテルを通じ，朝の飼料 給与直前から晚の搾乳前まで 1 時間間隔で計 10 サンプ ルを採取した。採取した血漼は $3,000 \mathrm{rpm}, 30$ 分の遠心 で血漿を分離後，分析サンプルとして凍結保存した。な お，最終的な個体ごよの血漿成分值は，この10サンプル の分析值を平均した值とした。

飼料，残飼，糞の一般成分および尿中 $\mathrm{N}$ は常法 ${ }^{8}$ に従 い, また, 飼料, 残飼, 䔬の NDF 和よび ADFはデター ジェント法 ${ }^{13)}$ ，港粉は過塩素酸抽出一グルコースオキシ ダーゼ比色法”により分析した。乳脂肪, 乳タンパク質, 乳糖の分析には赤外線自動分析計（ミルコスキャン 133 B，ホスエレクトリック社）を用いた。血嶈中の $\mathrm{Na}, \mathrm{K}$, $\mathrm{Cl}$, 尿素, グルコース, ケトン体, 乳酸, ピルビン酸, LDH 濃度书よび乳中之尿中の尿素濃度は自動生化学分 析装置（7250型，日立製作所）によって分析老行った。

Table 2. Chemical composition of feeds

\begin{tabular}{|c|c|c|c|c|c|c|c|c|c|}
\hline & $\mathrm{DM}$ & $\mathrm{OM}$ & $\mathrm{CP}$ & $\begin{array}{c}\text { Crude } \\
\text { fat }\end{array}$ & NFE & $\begin{array}{c}\text { Crude } \\
\text { fiber }\end{array}$ & $\mathrm{NDF}$ & $\mathrm{ADF}$ & Starch \\
\hline & $(\%)$ & \multicolumn{8}{|c|}{$\cdots(\% \mathrm{DM})$} \\
\hline Basal diet* & 70.0 & 93.2 & 19.4 & 2.9 & 51.2 & 19.9 & 36.7 & 24.8 & 12.3 \\
\hline Grass silage* & 31.0 & 93.3 & 14.4 & 4. 2 & 42.6 & 32.0 & 56.4 & 38.9 & 1.1 \\
\hline Dried grass & 88.5 & 92.1 & 16.5 & 2.1 & 35.5 & 38.1 & 64.7 & 46. 1 & 0.7 \\
\hline Formula feed & 92.2 & 93.8 & 20.1 & 3.2 & 63.4 & 7.1 & 18.0 & 9.3 & 34.3 \\
\hline Beet pulp & 92.6 & 91.8 & 9.3 & 0.8 & 63.3 & 18.5 & 34.2 & 25.9 & 0.1 \\
\hline Soybean meal & 92.0 & 92.9 & 48.7 & 0.4 & 36.6 & 7.3 & 11.5 & 9.6 & 3.8 \\
\hline Potato starch & 81.6 & 99.7 & 1.1 & 0.0 & 98.6 & 0.0 & 0.0 & 0.0 & 95.4 \\
\hline
\end{tabular}

* Average value of three trial periods.

Anim. Sci. J. 72 (8) : J239-J246, 2001 
Table 3. Effect of purified potato starch supplementation on ratio of residual feed, intake of nutrients, sufficiency rate, and $\mathrm{TDN} / \mathrm{CP}$ ratio in lactating cows

\begin{tabular}{lcccc}
\hline \multirow{2}{*}{ Item } & \multicolumn{4}{c}{ supplementation } \\
\cline { 2 - 5 } & $0 \%$ & $10 \%$ & $20 \%$ & SEM \\
\hline Ratio of residual feed (\%) & $0.83^{\mathrm{a}}$ & $0.90^{\mathrm{a}}$ & $9.27^{\mathrm{b}}$ & 0.18 \\
Intake (kg/day) & & & & \\
DM & $21.50^{\mathrm{a}}$ & $23.43^{\mathrm{b}}$ & $23.23^{\mathrm{b}}$ & 0.08 \\
Water & 121.5 & 126.2 & 121.0 & 1.0 \\
TDN & $16.02^{\mathrm{a}}$ & $17.77^{\mathrm{b}}$ & $17.64^{\mathrm{b}}$ & 0.10 \\
CP & $4.16^{\mathrm{a}}$ & $4.18^{\mathrm{a}}$ & $3.91^{\mathrm{b}}$ & 0.01 \\
Sufficiency rate & & & & \\
TDN & & & & \\
CP & $117.6^{\mathrm{a}}$ & $127.4^{\mathrm{b}}$ & $128.4^{\mathrm{b}}$ & 0.9 \\
TDN/CP ratio & $154.5^{\mathrm{a}}$ & $151.4^{\mathrm{a}}$ & $144.1^{\mathrm{b}}$ & 0.9 \\
\hline
\end{tabular}

1: Water $=$ feed moisture + drinking water.

$2:$ Sufficiency rate $=$ intake $/$ requirement $\times 100$.

$a, b, c:$ Values with different superscripts differ $(P<0.05)$.

血嶈浸透厅の測定には浸透王計（OSA-22，日機装），第 一胃液 VFA 濃度の分析にはガスクロマトグラフ $\left(\mathrm{G}^{-}\right.$ 3000 型，日立製作所）をそれぞれ用いた。 また，血漿 $\alpha$ アミノ態 N濃度は DNP 法 ${ }^{18)}$ にりり測定し，第一胃液乃 ンモニア態 $\mathrm{N}$ 濃度は市販キット(アンモニアテスト，和 光純薬）を用いて分析した。

デー夕の統計好理にはSASの GLM プロシジャ211を 用いた。

\section{結果}

表 3 に各処理区ごとの残食率，摂取量（乾物，水分， $\mathrm{TDN}, \mathrm{CP}), \mathrm{TDN}$ 上CP充足率抢よび TDN/CP 比を示 した．飼料給与量を設定した馿致期間と比べ，試験期間 中に使用したサイレージの栄養価が高かったことおよび 乳量レベルが低下したことによって，TDNの給与レベ ルは当初の予定よりもかなり高いものとなり，0および 10\%区では給与全量をほぼ採食したすのの，20\%区で は平均 1 割弱の残食が生じた。その結果，実測のTDN 充足率は 10\%区之20\%区でほぼ同程度て，CP 充足率 は $20 \%$ 区が他の 2 区よりも低いよいう飼料条件になっ たが，TDN/CP 比は澱粉添加にともなって上昇した。水 分摂取量 (飼料水分十飲水) は処理区問で差がなかった。

各成分消化率，乳量求上び乳成分率に対する精製バレ
イショ測粉添加の効果表 4 にまよめた。消化率では， 有機物扰よびNFE 消化率が $0 \%$ 区に比べて港粉添加両 区で有意に上昇した。一力，粗脂肪およびNDF 消化率 は20\%区で有意に低下したが，いずれも3\%以内のわ ずかな低下であった。また，澱粉消化率はす心゙ての区で $100 \%$ に近い值か観察された，乳量には港粉添加の効果

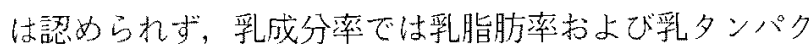
質率が測粉添加が增えるに従って上显する傾向にあった が，い式れむ統計的には有意な变化ではなかった。

粪量结 $10 \%$ 区がやや多い傾向にあったものの，各処 理区間に有意な差はなかった（表5)。しかし，冢量は澱 粉添加量の増加にと屯なって減少し，20\%区の尿量は 0\%区の約 $80 \%$ まで有意な減少を示した。その絬果, 20\%区は翼尿合計量でも0\%区に対して有意に少なく なった。尿中への $\mathrm{N}$ 排泄量ないし $\mathrm{N}$ 排泄率（N排泄量/ $\mathrm{N}$ 摂取量 $\times 100$ )には，いずれも敗粉添加量に反比例した 有意な低下が諗められた。0\%区之比較した港粉添加区 の尿中 $\mathrm{N}$ 排泄率の低下率は，10\%区で約 16\%，20\%区 で約 $26 \%$ であった，同様に，翼尿合計の $\mathrm{N}$ 排泄量（率） 屯潵粉添加量の増加とと屯に低下する傾向走示したが， 港粉添加区の䔬中 $\mathrm{N}$ 排泄量（率）加増加傾向にあったた わに，0\%区との統計的な有意差が観察されたのは $20 \%$ 区のみであった。 
大谷・田鎖・上野

Table 4. Effect of purified potato starch supplementation on digestibility, milk yield, and milk composition in lactating cows

\begin{tabular}{lllll}
\hline \multirow{2}{*}{ Item } & \multicolumn{4}{c}{ supplementation } \\
\cline { 2 - 5 } & $0 \%$ & $10 \%$ & $20 \%$ & SEM \\
\hline Digestibility (\%) & & & & \\
OM & $76.93^{\mathrm{a}}$ & $78.14^{\mathrm{b}}$ & $78.23^{\mathrm{b}}$ & 0.15 \\
CP & 73.60 & 70.96 & 70.32 & 0.54 \\
Crude fat & $79.24^{\mathrm{a}}$ & $79.36^{\mathrm{a}}$ & $76.51^{\mathrm{b}}$ & 0.41 \\
NFE & $83.55^{\mathrm{a}}$ & $85.49^{\mathrm{b}}$ & $85.56^{\mathrm{b}}$ & 0.24 \\
Crude fiber & 62.74 & 62.66 & 60.15 & 0.86 \\
NDF & $60.22^{\mathrm{a}}$ & $60.12^{\mathrm{a}}$ & $57.48^{\mathrm{b}}$ & 0.19 \\
ADF & 60.12 & 60.17 & 57.03 & 0.98 \\
Starch & 97.12 & 98.43 & 98.65 & 0.22 \\
Milk yield (kg/day) & 29.0 & 30.0 & 28.7 & 0.45 \\
Milk composition (\%) & & & & \\
Fat & 3.71 & 3.73 & 3.90 & 0.11 \\
Protein & 3.26 & 3.28 & 3.35 & 0.02 \\
Lactose & 4.37 & 4.41 & 4.37 & 0.04 \\
\hline
\end{tabular}

$a, b, c:$ Values with different superscripts $\operatorname{differ}(\mathrm{P}<$ 0.05 )

精製バレイショ敗粉添加による各種生体液中の成分变 化を表 6 に示した。尿中尿素態 $\mathrm{N}$ 濃度は澱粉添加で低 下する傾向を示したが，統計的に有意な变化ではなかっ た。第一胃液では澌粉添加量の増加につれて $\mathrm{pH}$ とアン モニア態 $\mathrm{N}$ 濃度の低下，VFA 濃度の上昇が見られ, 統 計的にはアンモニア態 $\mathrm{N}$ 濃度之酢酸濃度は各区間に, その他の成分については $0 \%$ 区と $20 \%$ 区の間に有意な 差が観察された，血漿成分では尿素態 $\mathrm{N}$ 濃度が明らか に澱粉添加量に反比例して低下し，乳酸招よびピルビン 酸濃度は測粉添加而区が0\%区より古有意に低值を示し た。逆に，グルコースと LDH 濃度は統計的に有意では ないるのの，激粉添加区が 0\%区よりも高くなる傾向に あった，血漿 $\alpha$ ア、，態 $\mathrm{N}$, ナトリウム，力リウム，塩 素濃度扣よび浸透圧には澱粉添加による傾可のある变化 は認められなかった，乳中尿素態 $\mathrm{N}$ 濃度は血漿と同様 に潵粉添加量に反比例した有意抵下低下示した。

\section{考察}

本試験で用いた基礎飼料中の主たる粗飼料源であるグ ラスサイレージは，その発䣲調製過程で原料草に含まれ
Table 5. Effect of purified potato starch supplementation on excreta, $\mathrm{N}$ intake, $\mathrm{N}$ excretion, and $\mathrm{N}$ excretory rate in lactating cows

\begin{tabular}{lllll}
\hline \multirow{2}{*}{ Item } & \multicolumn{4}{c}{ supplementation } \\
\cline { 2 - 5 } & $0 \%$ & $10 \%$ & $20 \%$ & SEM \\
\hline Excreta $(\mathrm{kg} /$ day $)$ & & & & \\
Feces & 42.5 & 44.8 & 42.9 & 0.6 \\
$\quad(\mathrm{DM})$ & $(5.4)$ & $(5.5)$ & $(5.5)$ & $(0.1)$ \\
Urine & $22.1^{\mathrm{a}}$ & $19.8^{\mathrm{ab}}$ & $17.3^{\mathrm{b}}$ & 0.7 \\
Total & $64.6^{\mathrm{a}}$ & $64.6^{\mathrm{a}}$ & $60.1^{\mathrm{b}}$ & 0.4 \\
$\mathrm{~N}$ intake (g/day) & $665.9^{\mathrm{a}}$ & $668.8^{\mathrm{a}}$ & $625.0^{\mathrm{b}}$ & 1.0 \\
$\mathrm{~N}$ excretory (g/day) & & & & \\
Feces & 175.7 & 194.3 & 185.1 & 3.7 \\
Urine & $261.5^{\mathrm{a}}$ & $220.3^{\mathrm{b}}$ & $183.3^{\mathrm{c}}$ & 2.6 \\
Total & $437.3^{\mathrm{a}}$ & $414.7^{\mathrm{a}}$ & $368.3^{\mathrm{b}}$ & 6.3 \\
N excretory rate* (\%) & & & & \\
Feces & 26.4 & 29.0 & 29.7 & 0.5 \\
$\quad$ Urine & $39.1^{\mathrm{a}}$ & $32.9^{\mathrm{b}}$ & $29.1^{\mathrm{c}}$ & 0.4 \\
Total & $65.5^{\mathrm{a}}$ & $61.9^{\mathrm{ab}}$ & $58.8^{\mathrm{b}}$ & 0.8 \\
\hline
\end{tabular}

$*: \mathrm{N}$ excretory rate $=\mathrm{N}$ excretion $/ \mathrm{N}$ intake $\times 100$.

$\mathrm{a}, \mathrm{b}, \mathrm{c}$ : Values with different superscripts differ $(\mathrm{P}<$ $0.05)$.

るタンパク質の多くが可溶化される一方で，ほ上んよ゙の 可溶性炭水化物が消費されてしまうため， $\mathrm{N}$ 成分の第一 胃内分解速度が非常に速いに良加からず，それを第一 胃微生物が取り込むために必要なエネルギ一源が不足す ることとなり，有効に利用されない $\mathrm{N}$ が多いという特 性がある゙”，また，泌乳牛では飼料中の $\mathrm{N}$ 含量が $24 \mathrm{~g} /$ $\mathrm{kgDM}$ 以上になると第一胃における $\mathrm{N}$ 損失が顕著にな ることが報告されているが24!, 今回の基礎飼料中 $\mathrm{N}$ 含量 は $31 \mathrm{~g} / \mathrm{kgDM}$ とかなり高いレベルであった。 したがっ て、本試験で設定した $0 \%$ 区は，相当な飼料 $\mathrm{N}$ の無駄が 生じる飼料条件の例之言える。

今回の試験結果は，このような飼料条件において，精 製バレイショ澌粉のような易発酵性炭水化物の添加が有 効であることを㹬明した。すなわち，澱粉添加は尿中へ

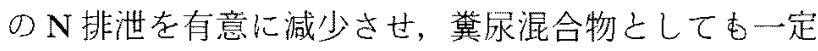
の $\mathrm{N}$ 低减効果が期待できた。 また，尿量自体を减少させ る効果屯あったため，添加により乾物撕取量が増加した にむかかわらず，合計の排泄物量の増加屯抑えられた。

一方，飼料の消化性や乳量抢よび乳成分には大きな影響 
測粉添加による乳牛 $\mathrm{N}$ 排泄の低減

Table 6. Effect of purified potato starch supplementation on urine, ruminal fluid, plasma, and milk compornent in lactating cows

\begin{tabular}{|c|c|c|c|c|c|}
\hline \multirow{2}{*}{\multicolumn{2}{|c|}{ Item }} & \multicolumn{3}{|c|}{ supplementation } & \multirow{2}{*}{ SEM } \\
\hline & & \multirow[t]{2}{*}{$0 \%$} & \multirow[t]{2}{*}{$10 \%$} & \multirow[t]{2}{*}{$20 \%$} & \\
\hline Urine & & & & & \\
\hline Urea $\mathrm{N}$ & $(\mathrm{mgN} / \mathrm{d} l)$ & 679.3 & 598.7 & 568.3 & 26.1 \\
\hline \multicolumn{6}{|l|}{ Ruminal fluid } \\
\hline $\mathrm{pH}$ & & $7.00^{\mathrm{a}}$ & $6.94^{\mathrm{ab}}$ & $6.74^{b}$ & 0.04 \\
\hline Ammonia $\mathrm{N}$ & $(\mathrm{mgN} / \mathrm{d} l)$ & $9.73^{a}$ & $7.59^{\mathrm{b}}$ & $6.04^{c}$ & 0.11 \\
\hline Acetate & $(\mathrm{mmol} / \mathrm{d} l)$ & $3.60^{a}$ & $4.72^{6}$ & $5.51^{\mathrm{c}}$ & 0.11 \\
\hline Propionate & $(\mathrm{mmol} / \mathrm{d} l)$ & $1.14^{\mathrm{a}}$ & $1.21^{\mathrm{ab}}$ & $1.97^{b}$ & 0.13 \\
\hline Butyrate & $(\mathrm{mmol} / \mathrm{d} l)$ & $0.56^{\mathrm{a}}$ & $0.75^{\mathrm{ab}}$ & 1. $26^{\mathrm{b}}$ & 0.09 \\
\hline Total VFA & $(\mathrm{mmol} / \mathrm{d} l)$ & $5.88^{\mathrm{a}}$ & $7.27^{\mathrm{b}}$ & $9.60^{c}$ & 0.21 \\
\hline \multicolumn{6}{|l|}{ Plasma } \\
\hline Urea $\mathrm{N}$ & $(\mathrm{mgN} / \mathrm{d} l)$ & $16.8^{a}$ & $13.8^{b}$ & $1.1 .2^{\circ}$ & 0.3 \\
\hline$\alpha$-amino $\mathbf{N}$ & $(\mathrm{mgN} / \mathrm{d} l)$ & 4.48 & 4. 33 & 4.60 & 0.14 \\
\hline Glucose & $(\mathrm{mg} / \mathrm{d} l)$ & 73.0 & 77.3 & 76.6 & 1.2 \\
\hline Lactate & $(\mathrm{mg} / \mathrm{d} l)$ & $3.96^{\mathrm{a}}$ & 3. $38^{\mathrm{b}}$ & $3.43^{b}$ & 0.04 \\
\hline Pyruvate & $(\mu \mathrm{g} / \mathrm{d} l)$ & $408.0^{\mathrm{a}}$ & $393.2^{b}$ & $383.3^{6}$ & 2.4 \\
\hline $\mathrm{LDH}$ & $(W U)$ & 1,826 & 1,968 & 1.936 & 34 \\
\hline Osmolality & $(\mathrm{mOsm} / \mathrm{kg})$ & 285.4 & 285.4 & 284.4 & 0.7 \\
\hline $\mathrm{Na}$ & $(\mathrm{mEq} / l)$ & 138.2 & 138.9 & 138.5 & 0.4 \\
\hline $\mathrm{K}$ & $(\mathrm{mEq} / l)$ & 4.1 & 4. 1 & 4.2 & 0.1 \\
\hline $\mathrm{Cl}$ & $(\mathrm{mEq} / l)$ & 102.3 & 102.9 & 104.4 & 0.2 \\
\hline \multicolumn{6}{|l|}{ Milk } \\
\hline Urea $\mathrm{N}$ & $(\mathrm{mgN} / \mathrm{d} l)$ & $16.2^{\mathrm{a}}$ & $13.2^{6}$ & $11.5^{\circ}$ & 0.13 \\
\hline
\end{tabular}

$a, b, c:$ Values with different superscripts differ $(P<0.05)$.

を与えることはなかった。

反怱家畜への易発酵性炭水化物の給与に関しては，採 食性・消化性の低下や第一胃内環境の乱れなどの悪影響 が指摘されることも多い4.15). 本試験でも20\%区では残 食があり，粗脂肪とNDF 消化率の低下および第一胃液 $\mathrm{pH}$ の低下が観察された，当初の予定よりあ0\%区の TDN レベルが高めであったことから，この飼料条件に おける20\%という測粉添加量はエネルギ一的にやや過 剩であり，添加水準はこれより低く設定すべきと思われ た。しかし，かなり飳粉多給な飼料条件であった割には， 観察された低下の程度はいずれもわずかであり，いわ功 る㵋粉減退しいわれるような瀻維消化率の大きな低下や 重篤な第一胃アシドーシスが引き起こされることはな かった。
おそらく今回の添加処理では, 第一胃内の飼料 $\mathrm{N}$ 上 炭水化物の分解の速度がうまく調和し, 円滑な微生物に 占る $\mathrm{N}$ 利用方実現したもの上思わ机る。民口上うな微 生物活性の变化的第一胃液のアンモ二ア態 $\mathrm{N}$ 濃度の低 下とVFA 濃度の上昇という事実が示唆している。また， その調和を導き出した要因のひとつとして，精製バレイ ショ澱粉とグラスサイレージのTMR という給与形態が 考えられる。TMRは第一胃への偏った栄養素供給を防 ぐことで栄養素の利用性を高好る給与方法であるが24， とくに本試験のように水分の多いグラスサイレージと粉 末の精製バレイショ䀧粉を混合した場合には，測粉がサ イレージ付着して極朸て均一な状態となり，これが $\mathrm{N}$ と炭水化物の分解速度の同期化に好影響を与元九可能性 が考えられた。したがって，易発酵性炭水化物の添加技 
大谷・田銷・上野

術において，飼料および給与形態の選択は非常に重要と 思わ执る。

飼料中易発醅性炭水化物会量の增加に上る乳脂肪湐の 低下はしばしば指摘されるがは6,17)，本試験では乳脂肪渗 の低下は認められなかった。これは今回の添加処理が第 一胃内VFA 性状に及ぼした効果が，プロピオン酸漕度 のみを高めるものではなく，酢酸や酪酸なよ゙の漂度む上 昇させるものであったことによる上思わ机る。一方，乳 タンパク質率は若干の上昇傾向にあったものの, 乳量上 もど屯有意な变化は示さなかった。すなわち，乳牛の掑 取 Nの分配は，澱粉添加によって排泄への割合が減る むのの，无れが乳生産に䢙る分はごくわずかであり，多 くは体蓄積に迴ったという結果であった，供試牛が泌乳 中後期牛であったことが，余ったNの流れを体蓄積の 万向に向かわせたものとも考元られ，エネルギー不足の 泌乳最盛期の乳牛では異なった反応か観察されたかもし れない，今後，排泄 $\mathrm{N} の$ 低减化に加元，そのN 0 生産物

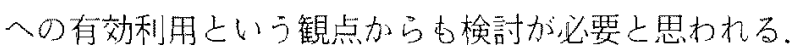

今回の尿中 $\mathrm{N}$ 排泄量の減少は, 尿量の減少上尿中 $\mathrm{N}$ 濃度の低下によるものである。尿中 $\mathrm{N}$ はその半分以上 が尿素態であり，その起源となる血漿录素態 $\mathrm{N}$ 濃度に 明らかな低下が観察されたことを考えれば，傾向として 観察された尿中尿素態 $\mathrm{N}$ 濃度の低下は，澌粉添加によ る尿中の $\mathrm{N}$ 濃度低下の大きな要因のひとつであったと 考えられる。一方, 尿量の減少については, 主要な尿量 規制因子と考えら扎る摃取水量, 血漿浸透圧, 血漿ミ不 ラル濃度等25には变化が認められなかった，Godwin 上 Williams $^{6}$ は上ツジを用いた第一胃内尿素注入実騃におう いて，血漿尿素濃度の上昇に上もなう疗量の増加を報告 している。また，ヤギの脳室内への㽷素注入実験の結果 から，尿素には抗利尿ホルモン（ADH）の放出抑制作用 があることが示唆されている20!。したがって，反笉家音 に扮いては血浆尿素濃度の変動も尿量を規制する一因子 であると考えられる。本試験では ADH の動態は調べて いないが，他の規制因子にまったく変化が見られないこ

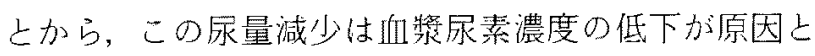
なった可能性が高いと思われる。

このように測粉添加による尿中 N排泄量減少のメ力 ニズムにおいて，血漿尿素濃度の低下が重要な役割を果 たしていると思わ机る。この血漿永素濃度の変化を引き 起こした主たる要因のひとつが，第一胃液アンモニア態 $\mathrm{N}$ 濃度の低下であったことは疑いのないところと思わ れるが，加元て，糖新生における代謝変化本関与したの ではないか子推測される，すなわち，澱粉添加による第 一胃内プロピオン酸産生量の増加は，糖新生基質として
より多くのプロピオン酸の利用を可能にすると考えられ る。また，激粉添加区で観察された糖新生基質の乳酸お よびピルビン酸の血漿濃度の低下と両基質の転換反応を 触媒する LDH 活性の上昇傾向は，ウシの肝臟に抢いて 糖新生律速酵素のピルビン酸カルボキシラーゼ活性を增 强するアセチル $\operatorname{CoA}^{21}$ の供給源である酢酸と酪酸の第 一胃内産生量が增加しているという背景を考慮す机ば, 乳酸上ピルビン酸からの糖新生むえ進したことを示唆す るむの上考えられる：このようなアミノ酸以外の基質か らの糖新生が增加した之すれば，相対的に糖新生基質之 して買化されるアミ，酸加減少し（アミ，酸の節約効 果), 結果的に血㢡尿素濃度低下に貢献した可能性が考

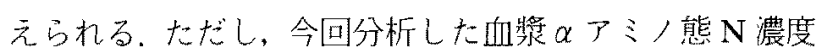
には傾向のある变化は認められなかったので，この推測 を裏付けるためには，今後，個々の糖原性アミノ酸の代 謝動態老明らかにする研究が必要である。

さらに言及するならば，近年，乳牛のタンパク栄養状 態(9)や尿中への N 損失状態”の指標として，血獎尿素濃 度を反映しかつサンプリングが容易な乳中尿素濃度が注 目されているが，本試験の結果で㿝乳中尿素濃度と尿中 $\mathrm{N}$ 排泄量の間に高い相関関係 $(\mathrm{r}=0.9166, \mathrm{P}<0.01)$ が認 められた。こ机まで考察したように, 澱粉添加による尿 中 $\mathrm{N}$ 排泄量隇少のメカ二ズムに血漿尿素濃度が重要な 役割を果たしていることを考えれば，その变化を反映す る乳中尿素濃度を指標として尿中 $\mathrm{N}$ 排泄量を推定する という考え万は納得できるものである。したがって，今 後は易発酵性炭水化物添加による乳牛の N 排泄量低減 化技術に関して研究を進めるに際し，N 低減効果の推定 指標として乳中尿素濃度孝有効に利用していくことが推 奖さ机る。

\section{文献}

1) Aldrich JM, Muller LD, Varga GA, Griel LC Jr. Nonstructural carbohydrate and protein effects on rumen fermentation, nutrient flow, and performance of dairy cows. Journal of Dairy Science, 76:1091-1105. 1993.

2) Black AL, Luick J, Moller F, Anand RS. Pyruvate and propionate metabolism in lactating cows. Effect of butyrate on pyruvate metabolism. The Journal of Biological Chemistry, $241: 5233-5237.1966$.

3) Ciszuk P, Gebregziabher T. Milk urea as an estimate of urine nitrogen of dairy cows and goats. Acta Agriculturae Scandinavica Sect.A Animal Science, 44 : 87-95. 1994.

4) England P, Gill M. The effect of fish meal and sucrose supplementation on the voluntary intake of grass silage and live weight gain of young cattle. Animal Production, 40 : 259-265. 1985.

5) French N, Kennelly JJ. Effects of feeding frequency on 
ruminal parameters, plasma insulin, milk yield, and milk composition in Holstein cows. Journal of Dairy Science, $73: 1857-1863,1990$.

6) Godwin IR, Williams VJ. Renal control of plasma urea level in sheep : The diuretic effect of urea, potassium and sodium chloride. Quarterly Journal of Experimental Physiology, $69: 49-59.1984$.

7) Haga K. Animal waste problems and their solution from the technological point of view in Japan. Japan Agricultural Research Quarterly, 32 : 203-210. 1998.

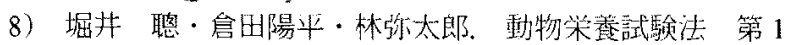
版（森本 宏監修）280-298. 養賢堂. 東京. 1971 .

9)自給飼料品螅評価研究会編。粗飼料の品翼評価ガイド ブック．日本草地協会．東京１994.

10) McCarthy RD Jr, Klusmeyer TH, Vicini JL, Clark JH. Effects of source of protein and carbohydrate on ruminal fermentation and passage of nutrients to the small intestine of lactating cows. Journal of Dairy Science, $72: 2002-2016$. 1989.

11) McDonald $P$, Hendereson AR, Heron SJE. The Biochemistry of Silage. 2nd ed. 230-305. Chalcombe Publications. Marlow. 1991.

12）農林水産省技術会議事務局編. 日本䝭養標準・乳牛 (1994 年版)。中央畜産会。東宗。1994。

13）農林水産省音産試験場編. 新しい飼料分析法之その応 用。畜産試騟場資料 No.56-1.1981。

14) Obara Y, Dellow DW, Nolan JV. The influence of energyrich supplements on nitrogen kinetics in ruminants. In : Physiological Aspects of Digestion and Metabolism in Ruminants. (Tsuda T, Sasaki Y, Kawasima R eds.) 515-539. Academic Press. San Diego. 1990.

15) Offer NW, Axford RFE, Evans RA. The effect of dietary energy source on nitrogen metabolism in the rumen of sheep. British Journal of Nutrition, 40:35-44, 1978.

16) Poore $M H$, Moore JA, Swingle RS, Eck TP, Brown WH. Wheal straw or alfalfa hay in diets with $30 \%$ neutral detergent fiber for lactating Holstein cows. Journal of Dairy Science, 74 : 3152-3159, 1991.

17) Poore MH, Moore JA, Swingle RS, Eck TP, Brown WH. Response of lactating Holstein cows to diets varying in fiber source and ruminal starch degradability. Journal of Dairy Science, 76: 2235-2243. 1993.

18) Rapp RD. Determination of serum amino acids. Clinical Chemistry, $9: 27-30,1963$.

19) Roseler DK, Ferguson JD, Sniffen CJ, Herrema J. Dietary protein degradability effects on plasma and milk urea nitrogen and milk nonprotein nitrogen in Holstein cows. Journal of Dairy Science, $76: 525-534,1993$

20) Rundgren M, Eriksson S, Appelgren B. Urea-induced inhibition of antidiuretic hormone (ADH) secretion. Acta Physiologica Scandinavica, $106:$ 491-492. 1979.

21) SAS. SAS/STAT ユーザーズガイド 6.03版。 569-666. SAS 出版社. 東京. 1990

22) Sutoh M, Obara $Y$, Miyamoto $S$. The effect of sucrose supplementation on kinetics of nitrogen, ruminal propionate and plasma glucose in sheep. Joumal of Agricultural Science, $126:$ 99-105. 1996.

23) Syrjala L. Effect of Differnt sucrose, starch and glucose supplements on the utilization of grass silages by ruminants. Annales Agriculturae Fenniae, 11 : 199-276. 1972.

24) Tamminga $S$. Nutrition management of dairy cows as a contribution to pollution control. Joumal of Dairy Science, 75:345-357. 1992.

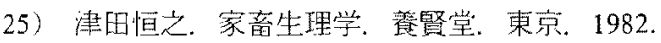




\title{
Influence of Readily Fermentable Carbohydrate Supplementation to the Diet on Nitrogen Excretion in Lactating Cows
}

\author{
Fumihiro OHTANI, Naozumi TAKUSARI and Takashi UENO \\ Hokkaido National Agricultural Experiment Station, Toyohira-ku, Sapporo-shi 062-8555, Japan \\ Corresponding : Fumihiro OHTANI (fax : +81 (0) 11-859-2178, e-mail : ayana@cryo.affrc.go.jp)
}

Three mid- or late-lactating Holstein cows were used in nitrogen $(\mathrm{N})$ balance trials to examine whether readily fermentable carbohydrate (RFC) supplementation to the diet can reduce $\mathrm{N}$ excretion without decline in productivity of lactating cows. Additionally, to determine the reduction mechanism by RFC supplementation, changes in urine, ruminal fluid, plasma, and milk components were examined. Basal diet was mainly composed of grass silage, and purified potato starch was used as RFC supplement. The cows were fed basal diet only, basal diet supplemented with $10 \%$ starch or basal diet supplemented with $20 \%$ starch according to $3 \times 3$ Latin square design. Although it was observed that crude fat and NDF digestibility and ruminal fluid $\mathrm{pH}$ decreased in the $20 \%$ starch supplementation, the extent of these changes were not large. There was no significant difference in milk yield and composition between treatments. Urinary $\mathrm{N}$ excretion or urinary $\mathrm{N}$ excretory rate ( $\mathrm{N}$ excretion/ $\mathrm{N}$ intake) reduced significantly in response to starch supplementation, the total (urine plus feces) $\mathrm{N}$ excretion or excretory rate was significantly lower in $20 \%$ starch supplementation than control. This reduction of urinary $\mathrm{N}$ excretion was due to the decrease in urine volume and urine urea concentration with starch supplementation, and it was thought that the decline in plasma urea concentration caused the decrease in urine. Two factors might be involved in this decline in plasma urea concentration, 1) the decline of ruminal fluid ammonia concentration which would result in the decrease of $\mathrm{N}$ supply to liver and 2) the increase in glucose production from propionate, lactate and pyruvate which would affect the sparing glucogenic amino acids.

The result in this study showed that supplementation with purified potato starch as RFC had a reducing effect on N excretion without much influence on feeding and milk performance in lactating cows and the decline in plasma urea concentration might play an important role in this reduction mechanism.

Animal Science Journal, 72 (8) : J239-J246, 2001

Key words : Lactating cows, Nitrogen excretion, Plasma urea, Readily fermentable carbohydrate, Potato starch 